\title{
PENERAPAN ALGORITMA K-MEANS PADA KOMPRESI ADAPTIF CITRA MEDIS MRI
}

\author{
I Wayan Angga Wijaya ${ }^{1}$ \\ anggaelectro@yahoo.com
}

Afriliana Kusumadewi ${ }^{2}$

\begin{abstract}
MRI medical image processing require large amounts of memory. Due to limited bandwidth and storage capacity, the image must be compressed prior to transmission and stored. This paper has the objective to implement the algorithm $k$ means the MRI medical image compression. Implementation begins with the Pre post. At this stage, L-dimensional vector of the image will be made. $L$ is the block - a measure used for clustering technique, but is set back in the form of an array. Then the process of clustering. At this stage, every pixel of the image is represented by the centroid of the cluster. And the last stage is the Main Compression, the pixels that do not contain important information will be removed. The study compared the quality of the original image and compressed image. Based on manual observation, there is no significant difference in quality between the original image and the compressed one.
\end{abstract}

Keywords: Digital, Image, Compression, Clustering, K Means

\section{Pendahuluan}

Dalam perkembangannya suatu citra tidak hanya sebagai dokumentasi dari kejadian yang pernah dialami. Namun kini suatu citra dapat menjadi alat bantu kepolisian untuk mencocokkan sidik jari seseorang sebagai alat enkripsi suatu data text menjadi sebuah data digital dan masih banyak lagi kegunaan-kegunaan lainnya. Sampai saat ini sudah banyak sekali aplikasi-aplikasi komersil pengolahan citra dapat mengolah berbagai macam citra dengan fungsi-fungsi yang cukup lengkap untuk melakukan pengolahan sebuah citra (Rohman \& Anisah, 2013).

Pengolahan citra pada masa sekarang mempunyai suatu aplikasi yang sangat luas dalam berbagai bidang kehidupan antara lain bidang arkeologi, astronomi, biomedis, bidang industri dan penginderaan jauh yang menggunakan teknologi citra satelit.

Pada bidang biomedis, citra yang sering digunakan citra MRI (Magnetic Resonance Imaging). Keunggulan citra MRI adalah kemampuan menampilkan detail anatomi secara jelas dalam berbagai potongan (multiplanar) tanpa mengubah posisi pasien (Riantini, 2011). Selain itu hasil pencitraan yang dihasilkan oleh MRI lebih jelas serta dapat dilihat dari berbagai sisi tanpa melibatkan pengunaan radiasi, memberikan hasil tanpa perlu mereposisi pasien, tidak menggunakan kontras untuk sebagian besar pemeriksaan MRI.

Namun salah satu kelemahan citra MRI adalah membutuhkan memori yang cukup besar. Sekali pemeriksaan citra medik jenis MRI dihasilkan puluhan citra medis.

Karena dibatasi bandwidth dan kapasitas penyimpanan, citra harus dikompresi sebelum dilakukan transmisi dan disimpan. Namun kompresi akan mengurangi ketelitian citra, terutama ketika citra yang dikompresi pada bitrate rendah (Rohman \& Anisah, 2013).

Kompresi citra digital merupakan upaya untuk melakukan transformasi terhadap data atau simbol penyusunan citra digital menjadi data atau simbol lain, tanpa menimbulkan perubahan yang signifikan atas citra digital tersebut bagi mata manusia yang mengamatinya. Tujuannya adalah untuk mengurangi redudansi dari data-data yang terdapat dalam citra sehingga dapat disimpan atau ditransmisikan secara efisien (Rohman \& Anisah, 2013).

Kompresi citra secara luas diklasifikasikan menjadi 2 yaitu teknik kompresi citra lossless compression dan lossy compression (Masatu, Soesanti, \& Nugroho, 2014). Lossless compression yaitu teknik yang memproses data asli menjadi bentuk yang lebih ringkas tanpa hilangnya informasi, biasanya digunakan pada aplikasi biomedis. Lossy compression yaitu

${ }^{1}$ Jurusan Teknik Elektro, Fakultas Teknik, Universitas Widya Dharma, Klaten

${ }^{2}$ Jurusan Teknik Elektro, Fakultas Teknik, Universitas Widya Dharma, Klaten 
teknik mendapatkan data yang lebih ringkas dengan melalui suatu proses penghampiran (aproksimasi) dari data asli dengan tingkat error yang dapat diterima. Teknik ini mengubah detail dan warna pada file citra menjadi lebih sederhana tanpa terlihat perbedaan yang mencolok dalam pandangan manusia, sehingga ukurannya menjadi lebih kecil. Biasanya digunakan pada citra foto atau image lain yang tidak terlalu memerlukan detail citra, dimana kehilangan bit rate foto tidak berpengaruh pada citra.

Penelitian ini dibuat sebagai usaha untuk mengefisiensikan penggunaan memori. Kompresi hanya akan dilakukan pada bagian tertentu yang dianggap bukan informasi penting yang perlu dipertahankan. Metode yang diterapkan pada penelitian ini adalah klasifikasi citra berupa clustering dengan tujuan untuk memisahkan objek utama dan latar.

Clustering adalah salah satu teknik yang digunakan dalam kompresi. Clustering itu sendiri merupakan proses pengelompokan data dalam kelas-kelas atau clusters sehingga datadata dalam suatu cluster memiliki tingkat persamaan yang tinggi satu dengan yang lainnya tetapi sangat berbeda dengan data pada cluster lain (Masatu, Soesanti, \& Nugroho, 2014). Metode $k$ means adalah salah satu teknik yang digunakan dalam segmentasi berbasis clustering. Clustering termasuk kedalam teknik lossy compression. Karena dengan tingkat kompresi yang tinggi, sehingga dapat menghemat banyak bandwidth.

Rumusan masalah dalam penelitian ini adalah bagaimana menerapkan algoritma $k$ means clustering pada kompresi adaptif citra medis MRI (Magnetic Resonance Imaging). Kompresi adaptif dipilih karena peta kode mampu beradaptasi terhadap perubahan karakteristik isi file selama proses kompresi berlangsung. Ini dikarenakan pada penelitian ini menggunakan citra dengan beberapa ekstensi.

Batasan masalah penelitian ini adalah citra medis MRI yang digunakan sebagai obyek penelitian adalah citra medis MRI otak baik yang normal atau yang mengalami lesi (gangguan). Citra medis MRI dikompresi menggunakan $k$ means clustering. Citra medis hasil kompresi dievaluasi berdasarkan parameter waktu kompresi, ratio kompresi, MSE, dan PSNR. Semua proses penelitian ini menggunakan software Matlab.

Tujuan dari penelitian ini adalah bagaimana membuat program yang mampu mengurangi ukuran citra medis MRI dengan berbagai ekstensi berkas agar dapat mengefisienkan penggunaan memori, namun kandungan informasi penting pada citra MRI masih tetap terjaga.

\section{Tinjauan Pustaka Dan Dasar Teori}

\subsection{Tinjauan Pustaka}

Penelitian tentang kompresi citra menggunakan algoritma clustering sudah banyak dilakukan diantaranya adalah penelitian yang dilakukan oleh Dika Asoka Masatu (Masatu, Soesanti, \& Nugroho, 2014). Penulis mengemukakan tentang kompresi Metode clustering Fuzzy C Means (FCM) dapat digabungkan dengan metode kompresi Joint-Photograpic Experts Group (JPEG) untuk menghasilkan kompresi citra berbasis entropi. Kompresi citra berbasis entropi yang dirancang dapat mempertahankan kandungan informasi yang penting dalam sebuah citra dengan cara tidak melakukan kompresi pada cluster dengan entropi rendah. Entropi yang rendah dalam sebuah cluster menandakan penyebaran pixel yang dimiliki hampir tidak seragam dan jumlahnya sedikit, sehingga dapat dianggap sebagai informasi penting dan di bagian ini tidak akan dikompresi. Sedangkan entropi yang tinggi menandakan penyebaran pixel-nya seragam dan jumlahnya banyak, sehingga dapat dianggap sebagai informasi yang kurang penting dan di bagian ini akan dikompresi.

Penelitian kompresi citra berikutnya dilakukan oleh Miftahur Rohman dan Ida Anisah menggunakan metode vector kuantisasi berbasis Fuzzy C Means (FCM) untuk melakukan proses kompresi citra (Rohman \& Anisah, 2013). Hasil yang diperoleh dari kompresi citra dengan menggunakan vektor kuantisasi tersebut dipengaruhi oleh panjang codebook, block vector pada citra, dan juga komposisi warna yang terdapat pada citra yaitu grayscale. Semakin tinggi codebook atau semakin kecil block vector yang digunakan maka semakin bagus kualitas citra yang telah dikompresi. Begitu juga sebaliknya, semakin rendah codebook atau semakin besar block vector yang digunakan maka semakin buruk kualitas citra yang 
telah dikompresi tersebut. Kualitas kompresi dari suatu citra juga dipengaruhi oleh komposisi warna yang tersebar dalam blok-blok citra.

\subsection{Dasar Teori}

\subsubsection{Citra Digital}

Sebuah citra adalah isyarat berbentuk dua dimensi yang diproses melalui interpretasi visual oleh mata manusia. Isyarat tersebut awalnya berbentuk analog, untuk mempermudah dalam pemrosesan dan penyimpanan maka isyarat tersebut diubah ke bentuk digital (Sutoyo, Eddy, Vincent, Oky, \& Wijanarto, 2009) (Gonzalez \& Woods, 2002). Satu-satunya cara untuk mengoptimalkan penyimpanan citra digital saat ini adalah dengan melakukan kompresi citra.

1. Citra Warna

RGB adalah suatu model warna yang terdiri dari merah, hijau, dan biru, digabungkan dalam membentuk suatu susunan warna yang luas (Sutoyo, Eddy, Vincent, Oky, \& Wijanarto, 2009) (Gonzalez \& Woods, 2002). Setiap warna dasar, misalnya merah, dapat diberi rentangnilai. Untuk monitor komputer, nilai rentangnya paling kecil $=0$ dan paling besar $=255$. Pilihan skala 256 ini didasarkan pada cara mengungkap 8 digit bilangan biner yang digunakan oleh mesin komputer. Dengan cara ini, akan diperoleh warna campuran sebanyak 256 x 256 x $256=1677726$ jenis warna.

2. Citra Grayscale

Graysacale adalah warna-warna piksel yang berada dalam rentang gradasi warna hitam dan putih (Sutoyo, Eddy, Vincent, Oky, \& Wijanarto, 2009) (Gonzalez \& Woods, 2002). Konversi citra berwarna RGB ke citra grayscale adalah dengan cara memberikan nilai bobot yang berbeda-beda pada setiap komponen RGB, seperti berikut ini: gray $=\left(0.3^{*} \mathrm{r}\right)+\left(0.5^{*} \mathrm{~g}\right.$ )$+(0.2 * b)$.

\subsubsection{Citra Medis Magnetic Resonance Imaging (MRI)}

MRI adalah suatu alat kedokteran di bidang pemeriksaan diagnostik radiologi, yang menghasilkan rekaman gambar potongan penampang organ manusia dengan menggunakan medan magnet (Riantini, 2011). Beberapa faktor kelebihan yang dimiliki oleh MRI adalah kemampuannya membuat potongan koronal, sagital, aksial tanpa banyak memanipulasi posisi tubuh pasien sehingga sangat sesuai untuk diagnostik jaringan lunak. Kualitas gambar MRI dapat memberikan gambaran detail tubuh manusia dengan perbedaan yang kontras, sehingga anatomi dan patologi jaringan tubuh dapat dievaluasi secara teliti.

\subsubsection{Kompresi}

Kompresi citra adalah proses mengurangi ukuran dari citra dengan mengurangi kualitas dari citra tersebut (Sutoyo, Eddy, Vincent, Oky, \& Wijanarto, 2009). Teknik kompresi citra dapat dibagi ke dalam dua kelompok, yaitu metode lossless dan lossy (Sutoyo, Eddy, Vincent, Oky, \& Wijanarto, 2009). Metode lossless akan mampu menghasilkan citra dekompresi yang sama persis dengan citra semula, namun rasio kompresi yang dihasilkan kecil. Sedangkan metode lossy akan menghasilkan rasio kompresi yang tinggi dengan mengorbankan kualitas dan kemampuan untuk mengembalikan citra ke ukuran aslinya.

\subsubsection{Clustering}

Proses pengelompokan sekumpulan obyek kedalam kelas-kelas obyek yang sama disebut clustering /pengelompokan (Jani, 2012). Cluster (klaster) adalah kesatuan nilai-nilai dalam jarak tertentu pada kepadatan suatu daerah (relatif besar) dibandingkan dengan kepadatan nilainilai daerah sekitarnya. Teknik klasterisasi bermanfaat untuk segmentasi citra dan klasifikasi data yang belum diolah untuk menciptakan kelas-kelas. Warna diwakili dalam vektor 3 dimensi dari nilai titiknya. Masing-masing komponen warna dihadirkan dalam warna merah, hijau dan biru (RGB). 


\subsubsection{K Means Clustering}

Algoritma K-Means adalah suatu algoritma pengelompokan objek berdasar pada atribut ke dalam pembagi $k$ (Masatu, Soesanti, \& Nugroho, 2014). Ini merupakan suatu varian algoritma maksimalisasi kemungkinan, dimana tujuanya adalah untuk menentukan $k$. Diasumsikan bahwa format atribut objek itu adalah suatu garis vektor ruang. Tujuanya adalah untuk memperkecil total perbedaan intra-cluster, atau fungsi (Gonzalez \& Woods, 2002).

$$
V=\sum_{i=1}^{k} \sum_{j \in S i}\left|x_{j}-\mu_{i}\right|^{2}
$$

Dengan ada $k$ klaster $i S, \mathrm{i}=1,2, \ldots, \mathrm{k}$ dan $\mu_{i}$ adalah pusat luasan atau titik dari semua poinpoin.

Proses klustering dimulai dengan mengidentifikasi data yang akan dikluster, $\boldsymbol{X} \mathbf{i j}$ $(\mathrm{i}=1, \ldots, \mathrm{n} ; \mathrm{j}=1, \ldots, \mathrm{m})$ dengan $\mathrm{n}$ adalah jumlah data yang akan dikluster dan $\mathrm{m}$ adalah jumlah variabel. Pada awal iterasi, pusat setiap kluster ditetapkan secara bebas (sembarang), $\boldsymbol{C} \boldsymbol{k j}$ $(\mathrm{k}=1, \ldots, \mathrm{k} ; \mathrm{j}=1, \ldots, \mathrm{m})$. Kemudian dihitung jarak antara setiap data dengan setiap pusat kluster. Untuk melakukan penghitungan jarak data ke-i (xi) pada pusat kluster ke-k (ck), dapat digunakan formula jarak Euclidean. Suatu data akan menjadi anggota dari kluster ke-k apabila jarak data tersebut ke pusat kluster ke-k bernilai paling kecil jika dibandingkan dengan jarak ke pusat kluster lainnya. Selanjutnya, kelompokkan data-data yang menjadi anggota pada setiap kluster (Narwati).

Nilai pusat kluster yang baru dapat dihitung dengan cara mencari nilai rata-rata dari data-data yang menjadi anggota pada kluster tersebut, dengan menggunakan persamaan berikut (Narwati):

Dimana $\boldsymbol{x i j} \in$ kluster ke $-\mathrm{k}$

$$
c_{k j}=\frac{\sum_{i=1}^{p} x_{i j}}{p}
$$

$\mathrm{p}$ = banyaknya anggota kluster ke $\mathrm{k}$

Berikut proses algoritma K-Means:

a. Data yang ada dipisahkan dalam kelompok-kelompok data (klaster) $k$ dan nilai-nlai data diacak ke dalam hasil-hasil kelompok data dalam kelompok data yang memiliki kesamaan jumlah dari nilai data.

b. Tiap nilai data dihitung menggunakan jarak Euclidean untuk tiap cluster.

c. Jika nilai data diwakili kelompok data tersendiri, biarkan, dan jika nilai data tak terwakili oleh kelompok data, pindah ke dalam kelompok data yang telah terwakili.

d. Ulangi langkah di atas sampai lengkap meliputi seluruh hasil nilai data dalam perpindahan satu cluster ke cluster lainnya

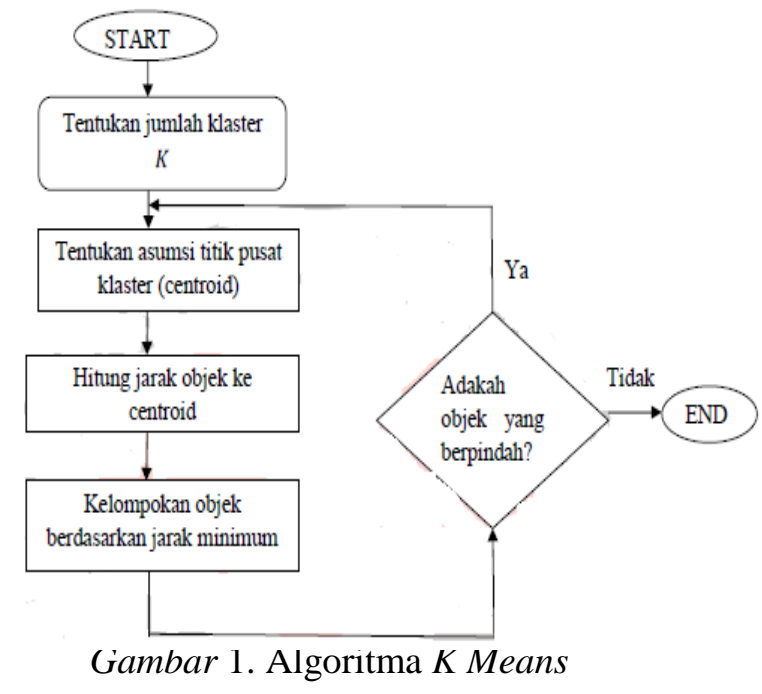

Prinsip dasar metode $k$ means adalah meminimumkan sum of square error (SSE) (Irwanto, Purwananto, \& Soelaiman., 2012): 


$$
S S E=\sum_{i=1}^{K} \sum_{x i \epsilon C i}(C i-X i)^{2}
$$

\subsubsection{Jarak Euclidean (Euclidean distance)}

Secara umum jarak Euclidean adalah jarak antara dua titik yang akan diukur pada satu, dua atau tiga dimensi. Berikut adalah posisi dari dua titik pada 3 dimensi; $P=\left(p_{x}, p_{y}, p_{z}\right)$, $Q=\left(q_{x}, q_{y}, q_{z}\right)$, sehingga jaraknya (Michaell):

$$
r=\sqrt{\left(p_{x}-q_{x}\right)^{2}+\left(p_{y}-q_{y}\right)^{2}+\left(p_{z}-q_{z}\right)^{2}}
$$

dengan P adalah nilai data dan Q adalah pusat dari kelompok data.

\subsubsection{Kualitas Kompresi}

Kualitas citra hasil kompresi dapat diukur secara kuantitatif menggunakan besaran PSNR (Peak Signal to Noise Ratio). Semakin besar nilai PSNR maka citra hasil kompresi semakin mendekati citra aslinya, dengan kata lain semakin bagus kualitas citra hasil kompresi tersebut. Sebaliknya, semakin kecil nilai PSNR semakin jelek kualitas citra hasil kompresi. Rumus untuk menghitung PSNR adalah sebagai berikut :

MSE (Mean Square Error), yaitu sigma dari jumlah error antara citra hasil segmentasi dan citra asli (Rohman \& Anisah, 2013).

$$
\mathrm{MSE}=\sqrt{\frac{\sum_{x=0}^{W-1} \sum_{y=0}^{H-1}\left(f(x, y)-f^{\prime}(x, y)\right)^{2}}{W H}}
$$

Dengan $\mathrm{f}(\mathrm{x}, \mathrm{y})$ adalah nilai pixel di citra asli, $\mathrm{f}^{\prime}(\mathrm{x}, \mathrm{y})$ adalah nilai pixel pada citra hasil kompresi, M,N adalah dimensi image (Rohman \& Anisah, 2013).

$$
\mathrm{PSNR}=20 \log _{10} \frac{255}{\mathrm{MSE}}
$$

Nilai MSE yang rendah akan lebih baik, sedangkan nilai PSNR yang tinggi akan lebih baik.

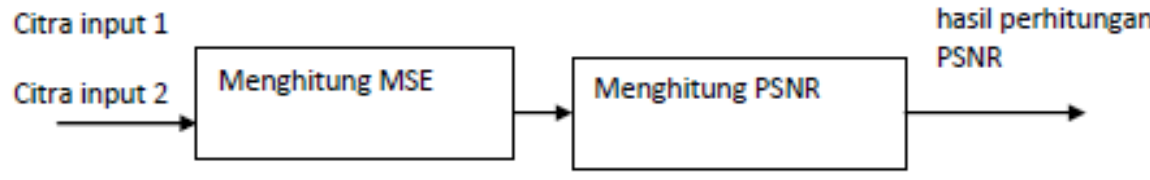

Gambar 2. Blok diagram menghitung Peak Signal to Noise Ratio (PSNR) menggunakan matlab

\subsubsection{Rasio Kompresi}

Rasio kompresi adalah perbandingan antara image asli dengan image hasil kompresi. Dengan melihat rasio kompresi, kita dapat mengetahui tingkat kompresi yang dihasilkan suatu metode kompresi, apakah metode tersebut cukup signifikan dalam mengurangi ukuran file image. Rasio kompresi dapat dihitung dengan rumus (Rohman \& Anisah, 2013):

$$
R=100 \%-\left[\frac{\text { outsize }}{\text { InSize }} \times 100 \%\right]
$$


Dengan R adalah rasio kompresi yang dinyatakan dalam persen. Outsize adalah ukuran file hasil kompresi (dalam bytes). Insize adalah ukuran file image asli (dalam bytes). Selain itu ada metode yang digunakan dalam bidang kompresi image yaitu BitRate dengan satuan bit per pixel (bpp) dengan rumus (Rohman \& Anisah, 2013):

$$
\text { BitRate }=\frac{8 \times(\text { OutSize })}{\text { InSize }}
$$

\section{Metode Penelitian}

Citra yang digunakan pada penelitian ini diperoleh dari www.sciencephoto.com (http://sciencephoto.com/). Citra yang digunakan adalah citra warna (color image) dan citra grayscale (grayscale image).

Peralatan yang digunakan dalam penelitian ini adalah perangkat keras (hardware) berupa sebuah laptop dengan spesifikasi : Sistem Komputer : Core 2 duo T5870, Sistem Operasi : Microsoft Windows 7, dan Memori : 2GB RAM dan perangkat lunak (software) Matlab R2013A dan Adobe Photoshop CS 3. Adobe photoshop digunakan untuk mengkonversi ekstensi citra. Citra digital yang uji coba terdiri dari 3 ekstensi yaitu : .BMP, .JPG, dan .PNG.

Penelitian ini melalui 3 tahap yaitu (Thyagarajan, 2011):

a. Pre post

Pada tahap ini akan dibuat vector L-dimensi dari citra. L adalah blok - ukuran yang digunakan untuk teknik clustering, tapi diatur kembali dalam bentuk array. Nilai input pixel dari citra diatur kembali dari bentuk matriks ke array.

b. Clustering

Pada tahap ini Setiap pixel dari citra direpresentasikan dengan centroid dari cluster.

c. Main Compression

Pada tahap ini pixel-pixel yang tidak mengandung informasi penting akan dihilangkan. Implementasi kompresi citra pada matlab :

- Membaca citra input

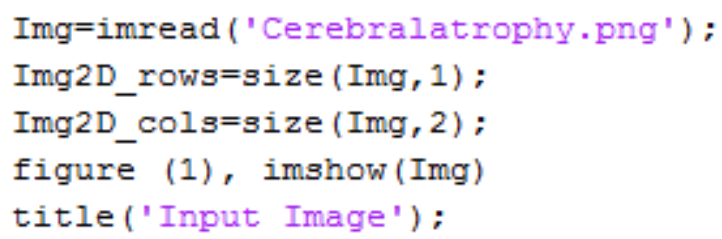

- Memeriksa apakah gambar input citra grayscale atau citra berwarna dan menerapkan k-means untuk 3 komponen (R, G, B) jika itu adalah citra berwarna.

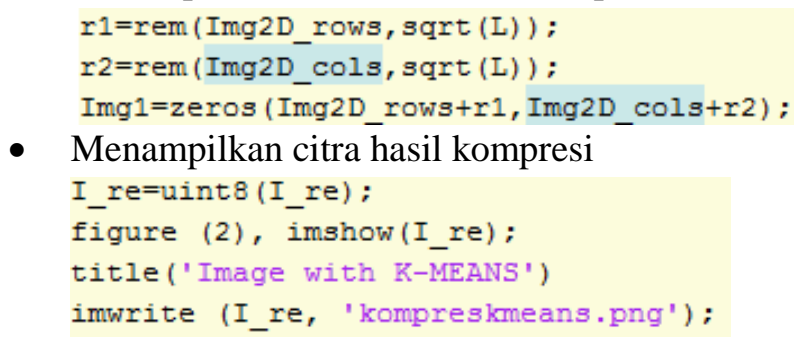

- Menampilkan citra hasil kompresi

I_re=uint8 (I_re) ;

figure (2), imshow(I_re);

title ('Image with K-MEANS')

imwrite (I_re, 'kompreskmeans.png') ;

Secara umum proses kompresi citra ditunjukkan oleh blok diagram pada Gambar 3.

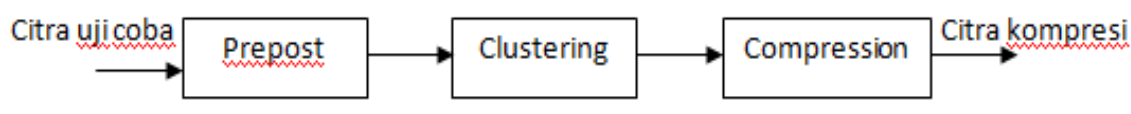

Gambar 3. Tahapan proses kompresi 
Program yang dirancang pada penelitian ini diharapkan mampu bekerja pada citra warma ataupun citra grayscale. Masing-masing citra hasil kompresi ada dihitung rasio kompresi, waktu kompresi, MSE, dan nilai PSNR.

\section{Hasil Dan Pembahasan}

Pada tahap ini dilakukan pengujian terhadap algoritma yang telah dirancang dan dibuat. Pada penelitian ini menggunakan 10 citra digital yaitu citra otak normal dan citra otak yang mengalami gangguan (lesi) namun dengan 3 ekstensi yang berbeda.

Tabel 1.

Citra MRI berwarna dengan kondisi normal

\begin{tabular}{|c|c|c|c|c|c|c|}
\hline No & Citra Asli & Citra Kompresi & $\begin{array}{c}\text { Waktu } \\
\text { Kompresi } \\
\text { (detik) }\end{array}$ & $\begin{array}{c}\text { Rasio } \\
\text { Kompresi } \\
(\%)\end{array}$ & MSE & PSNR \\
\hline \multirow[t]{2}{*}{1} & & & 233,29 & 50,49 & 0,00021 & 36,86 \\
\hline & $\begin{array}{l}\text { Otaknormal.png } \\
185 \mathrm{~KB}\end{array}$ & $\begin{array}{l}\text { Kompreskmeans.png } \\
91,6 \mathrm{~KB}\end{array}$ & & & & \\
\hline \multirow[t]{2}{*}{2} & & & 223,66 & 62,86 & 0,00019 & 37,25 \\
\hline & $\begin{array}{l}\text { Otaknormal.jpg } \\
63 \mathrm{~KB}\end{array}$ & $\begin{array}{l}\text { Kompreskmeans.jpg } \\
\text { 23,4 KB }\end{array}$ & & & & \\
\hline \multirow[t]{2}{*}{3} & & & 266,96 & 12,73 & 0,00015 & 38,19 \\
\hline & $\begin{array}{l}\text { Otaknormal.bmp } \\
597 \mathrm{~KB}\end{array}$ & $\begin{array}{l}\text { Kompreskmeans.bmp } \\
521 \mathrm{~KB}\end{array}$ & & & & \\
\hline
\end{tabular}


Tabel 2.

Citra MRI grayscale dengan kondisi normal

\begin{tabular}{|l|l|l|c|c|c|c|}
\hline No & \multicolumn{1}{|c|}{ Citra Asli } & Citra Kompresi & $\begin{array}{c}\text { Waktu } \\
\text { Kompresi } \\
\text { (detik) }\end{array}$ & $\begin{array}{c}\text { Rasio } \\
\text { Kompresi } \\
(\%)\end{array}$ & MSE & PSNR \\
\hline 1 & $\begin{array}{l}\text { Brain.png } \\
112 \mathrm{~KB}\end{array}$ & $48,6 \mathrm{~KB}$ & 300,18 & 56,61 & 0,0010 & 29,91 \\
\hline 2 & $\begin{array}{l}\text { Brain.jpg } \\
\text { 36,4 KB }\end{array}$ & $32 \mathrm{~KB}$ & 296,43 & 12,09 & 0,0012 & 29,01 \\
\hline 3 & $\begin{array}{l}\text { Brain.bmp } \\
824 \mathrm{~KB}\end{array}$ & $822 \mathrm{~KB}$ & 302,91 & 0,24 & 0,0009 & 30,30 \\
\hline
\end{tabular}

Tabel 3

Rata-rata perhitungan citra MRI dengan kondisi normal

\begin{tabular}{|l|l|l|l|l|l|}
\hline No & \multicolumn{1}{|c|}{ Ekstensi Citra } & $\begin{array}{c}\text { Waktu } \\
\text { Kompresi } \\
\text { (detik) }\end{array}$ & $\begin{array}{c}\text { Rasio } \\
\text { Kompresi (\%) }\end{array}$ & MSE & PSNR \\
\hline 1 & .png & 266,735 & 53,55 & 0,000605 & 33,385 \\
\hline 2 & .jpg & 260,045 & 37,475 & 0,000695 & 33,132 \\
\hline 3 & .bmp & 284,935 & 6,485 & 0,000535 & 34,425 \\
\hline
\end{tabular}

Citra pada tabel 1 dan 2 merupakan citra MRI dengan kondisi normal. Dari tabel 3 dapat dilihat bahwa program yang dirancang pada penelitian ini mampu bekerja pada citra dengan ekstensi yang berbeda.

a. Hasil kompresi

Berdasarkan hasil pada tabel 3 terlihat bahwa secara visual dari ketiga citra uji coba tersebut, hasil kompresinya masih terlihat jelas antara obyek citra dan latar belakang. Ketiga citra hasil kompresi tersebut masih terlihat dengan jelas bahwa citra tersebut citra dengan otak normal (tanpa lesi/gangguan).

b. Rasio kompresi

Berdasarkan hasil pada tabel 3 terlihat bahwa citra dengan ekstensi “.png” memiliki rasio kompresi paling besar dibandingkan kedua citra uji coba lainnya yaitu 53,55\% . Sedangkan citra ekstensi “.bmp” memiliki rasio kompresi paling kecil yaitu 6,485\%. Artinya citra dengan ekstensi ".bmp” paling sedikit kehilangan informasi ketika dikompresi dibandingkan dengan citra ekstensi “.jpg” dan citra ekstensi “.png”.

c. Waktu kompresi

Berdasarkan hasil pada tabel 3 terlihat bahwa citra uji dengan ekstensi ".bmp" membutuhkan waktu yang lebih lama dibandingkan dengan citra dengan ekstensi “.png” dan “.jpg” yaitu sebesar 284,935 detik. Sedangkan waktu kompresi paling cepat adalah citra dengan ekstensi “.jpg” yaitu sebesar 260,045 detik.

d. MSE

Berdasarkan hasil pada tabel 3 terlihat bahwa nilai MSE paling kecil adalah citra dengan ekstensi “.bmp” yaitu sebesar 0,000535. Ini menunjukkan citra kompresi ekstensi “.bmp” lebih mirip dengan citra aslinya dibandingkan dengan citra ekstensi “.jpg” dan “.png”.

e. PSNR

Berdasarkan hasil pada tabel 3 terlihat bahwa citra dengan ekstensi “.bmp” memiliki nilai PSNR paling besar dibandingkan kedua citra uji coba lainnya yaitu sebesar 34,425. Sedangkan citra ekstensi “.png” sebesar 33,385 dan citra ekstensi “.jpg” sebesar 33.132. Ini menunjukkan kualitas kompresi citra ekstensi “.bmp” lebih bagus dibandingkan dengan citra ekstensi “.png” dan “.jpg” 
Tabel 4.

Citra MRI berwarna dengan kondisi terdapat gangguan (lesi)

\begin{tabular}{|l|l|l|c|c|c|c|}
\hline No & \multicolumn{1}{|c|}{ Citra Asli } & Citra Kompresi & $\begin{array}{c}\text { Waktu } \\
\text { Kompresi } \\
(\text { detik) }\end{array}$ & $\begin{array}{c}\text { Rasio } \\
\text { Kompresi } \\
(\%)\end{array}$ & MSE & PSNR \\
\hline 1 & $\begin{array}{l}\text { tumormeningioma.png } \\
183 \mathrm{~KB}\end{array}$ & $125 \mathrm{~KB}$ & 127,25 & 31,69 & 0.0011 & 31,52 \\
\hline 2 & $\begin{array}{l}\text { tumormeningioma.jpg } \\
71 \mathrm{~KB}\end{array}$ & $26,1 \mathrm{~KB}$ & 120,36 & 63,23 & 0.0016 & 27,98 \\
\hline 3 & $\begin{array}{l}\text { tumormeningioma.bmp } \\
\text { 344 KB }\end{array}$ & $343 \mathrm{~KB}$ & 127,39 & 0,29 & 0.0009 & 31,91 \\
\hline
\end{tabular}

Tabel 5.

Citra MRI berwarna dengan kondisi terdapat gangguan (lesi)

\begin{tabular}{|l|l|l|c|c|c|c|}
\hline No & \multicolumn{1}{|c|}{ Citra Asli } & Citra Kompresi & $\begin{array}{c}\text { Waktu } \\
\text { Kompresi } \\
(\text { detik) }\end{array}$ & $\begin{array}{c}\text { Rasio } \\
\text { Kompresi } \\
(\%)\end{array}$ & MSE & PSNR \\
\hline 1 & $\begin{array}{l}\text { tumormetatastik.png } \\
142 \mathrm{~KB}\end{array}$ & $90,5 \mathrm{~KB}$ & 109,21 & 36,26 & 0,0013 & 29,04 \\
\hline 2 & $\begin{array}{l}\text { tumormetatastik.jpg } \\
69,5 \mathrm{~KB}\end{array}$ & $23 \mathrm{~KB}$ & 108,44 & 66,91 & 0,0011 & 29,50 \\
\hline 3 & $\begin{array}{l}\text { tumormetatastik.bmp } \\
300 \mathrm{~KB}\end{array}$ & $298 \mathrm{~KB}$ & 110,45 & 0,66 & 0,0010 & 29,97 \\
\hline
\end{tabular}

Tabel 6.

Citra MRI berwarna dengan kondisi terdapat gangguan (lesi)

\begin{tabular}{|l|l|l|c|c|c|c|}
\hline No & \multicolumn{1}{|c|}{ Citra Asli } & Citra Kompresi & $\begin{array}{c}\text { Waktu } \\
\text { Kompresi } \\
(\text { detik })\end{array}$ & $\begin{array}{c}\text { Rasio } \\
\text { Kompresi } \\
(\%)\end{array}$ & MSE & PSNR \\
\hline 1 & $\begin{array}{l}\text { Alzheimerbrain.png } \\
425 \mathrm{~KB}\end{array}$ & $195 \mathrm{~KB}$ & 282,50 & 54,11 & 0,0011 & 29,97 \\
\hline 2 & $\begin{array}{l}\text { Alzheimerbrain.jpg } \\
398 \mathrm{~KB}\end{array}$ & $120 \mathrm{~KB}$ & 280,06 & 69,85 & 0,0013 & 29,55 \\
\hline 3 & $\begin{array}{l}\text { Alzheimerbrain.bmp } \\
811 \mathrm{~KB}\end{array}$ & $810 \mathrm{~KB}$ & 283,82 & 0,12 & 0,0010 & 30,20 \\
\hline
\end{tabular}


I Wayan Angga Wijaya, Afriliana Kusumadewi

Tabel 7.

Citra MRI berwarna dengan kondisi terdapat gangguan (lesi)

\begin{tabular}{|l|l|l|c|c|c|c|}
\hline No & \multicolumn{1}{|c|}{ Citra Asli } & Citra Kompresi & $\begin{array}{c}\text { Waktu } \\
\text { Kompresi } \\
\text { (detik) }\end{array}$ & $\begin{array}{c}\text { Rasio } \\
\text { Kompresi } \\
(\%)\end{array}$ & MSE & PSNR \\
\hline 1 & $\begin{array}{l}\text { Astrocytoma.png } \\
266 \mathrm{~KB}\end{array}$ & $115 \mathrm{~KB}$ & 224,92 & 56,79 & 0,0013 & 30,86 \\
\hline 2 & $\begin{array}{l}\text { Astrocytoma.jpg } \\
158 \mathrm{~KB}\end{array}$ & $71 \mathrm{~KB}$ & 229,19 & 55,06 & 0,0014 & 29,33 \\
\hline 3 & $\begin{array}{l}\text { Astrocytoma.bmp } \\
619 \mathrm{~KB}\end{array}$ & $617 \mathrm{~KB}$ & 218,21 & 0,32 & 0,0012 & 30,92 \\
\hline
\end{tabular}

Tabel 8.

Citra MRI berwarna dengan kondisi terdapat gangguan (lesi)

\begin{tabular}{|l|l|l|c|c|c|c|}
\hline No & \multicolumn{1}{|c|}{ Citra Asli } & Citra Kompresi & $\begin{array}{c}\text { Waktu } \\
\text { Kompresi } \\
(\text { detik) }\end{array}$ & $\begin{array}{c}\text { Rasio } \\
\text { Kompresi } \\
(\%)\end{array}$ & MSE & PSNR \\
\hline 1 & $\begin{array}{l}\text { Benignbraintumour.png } \\
281 \text { KB }\end{array}$ & $235 \mathrm{~KB}$ & 271,65 & 16,37 & 0,0013 & 30,05 \\
\hline 2 & $\begin{array}{l}\text { Benignbraintumour.jpg } \\
\text { 192 KB }\end{array}$ & $102 \mathrm{~KB}$ & 272,65 & 46,87 & 0,0014 & 28,95 \\
\hline 3 & $\begin{array}{l}\text { Benignbraintumour.bmp } \\
757 \text { KB }\end{array}$ & $750 \mathrm{~KB}$ & 274,89 & 0,92 & 0,0011 & 30,42 \\
\hline
\end{tabular}

Tabel 9.

Citra MRI berwarna dengan kondisi terdapat gangguan (lesi)

\begin{tabular}{|l|l|l|c|c|c|c|}
\hline No & \multicolumn{1}{|c|}{ Citra Asli } & Citra Kompresi & $\begin{array}{c}\text { Waktu } \\
\text { Kompresi } \\
(\text { detik })\end{array}$ & $\begin{array}{c}\text { Rasio } \\
\text { Kompresi } \\
(\%)\end{array}$ & MSE & PSNR \\
\hline 1 & $\begin{array}{l}\text { StrokeMRI.png } \\
295 \text { KB }\end{array}$ & $146 \mathrm{~KB}$ & 255,93 & 50,51 & 0,0012 & 29,40 \\
\hline 2 & $\begin{array}{l}\text { StrokeMRI.jpg } \\
65,5 \mathrm{~KB}\end{array}$ & $43,5 \mathrm{~KB}$ & 262,91 & 31,49 & 0,0013 & 29,31 \\
\hline 3 & $\begin{array}{l}\text { StrokeMRI.bmp } \\
714 \text { KB }\end{array}$ & $710 \mathrm{~KB}$ & 264,57 & 0,56 & 0,0011 & 29,59 \\
\hline
\end{tabular}


Tabel 10.

Citra MRI berwarna dengan kondisi terdapat gangguan (lesi)

\begin{tabular}{|l|l|l|c|c|c|c|}
\hline No & \multicolumn{1}{|c|}{ Citra Asli } & Citra Kompresi & $\begin{array}{c}\text { Waktu } \\
\text { Kompresi } \\
(\text { detik) }\end{array}$ & $\begin{array}{c}\text { Rasio } \\
\text { Kompresi } \\
(\%)\end{array}$ & MSE & PSNR \\
\hline 1 & $\begin{array}{l}\text { Cerebralatrophy.png } \\
339 \mathrm{~KB}\end{array}$ & $206 \mathrm{~KB}$ & 230.15 & 39,23 & 0,0013 & 32.34 \\
\hline 2 & $\begin{array}{l}\text { Cerebralatrophy.jpg } \\
\text { 203 KB }\end{array}$ & $102 \mathrm{~KB}$ & 222,83 & 49,75 & 0,0014 & 31,21 \\
\hline 3 & $\begin{array}{l}\text { Cerebralatrophy.bmp } \\
658 \mathrm{~KB}\end{array}$ & $652 \mathrm{~KB}$ & 231,03 & 0,91 & 0,0012 & 32,98 \\
\hline
\end{tabular}

Tabel 11.

Citra MRI grayscale dengan kondisi terdapat gangguan (lesi)

\begin{tabular}{|l|l|l|c|c|c|c|}
\hline No & \multicolumn{1}{|c|}{ Citra Asli } & Citra Kompresi & $\begin{array}{c}\text { Waktu } \\
\text { Kompresi } \\
\text { (detik) }\end{array}$ & $\begin{array}{c}\text { Rasio } \\
\text { Kompresi } \\
(\%)\end{array}$ & MSE & PSNR \\
\hline 1 & $\begin{array}{l}\text { brain stroke.png } \\
144 \mathrm{~KB}\end{array}$ & $90,8 \mathrm{~KB}$ & 286,23 & 36,94 & 0,0011 & 29,57 \\
\hline 2 & $\begin{array}{l}\text { brain stroke.jpg } \\
99,4 \mathrm{~KB}\end{array}$ & $31,6 \mathrm{~KB}$ & 284,72 & 68,21 & 0,0025 & 26,05 \\
\hline 3 & $\begin{array}{l}\text { brain stroke.bmp } \\
782 \mathrm{~KB}\end{array}$ & $781 \mathrm{~KB}$ & 288,32 & 0,13 & 0,0010 & 29,91 \\
\hline
\end{tabular}

Tabel 12.

Rata-rata perhitungan citra MRI dengan kondisi terdapat gangguan (lesi)

\begin{tabular}{|l|l|l|l|l|l|}
\hline No & \multicolumn{1}{|c|}{ Ekstensi Citra } & $\begin{array}{c}\text { Waktu Kompresi } \\
\text { (detik) }\end{array}$ & \multicolumn{1}{|c|}{$\begin{array}{c}\text { Rasio Kompresi } \\
(\%)\end{array}$} & MSE & PSNR \\
\hline 1 & .png & 223,48 & 40,24 & 0,00121 & 29,718 \\
\hline 2 & .jpg & 222,64 & 56,42 & 0,00152 & 28,958 \\
\hline 3 & .bmp & 224,84 & 0,48 & 0,00106 & 30,737 \\
\hline
\end{tabular}

Citra pada tabel 4 , tabel 5 , tabel 6 , tabel 7 , tabel 8 , tabel 9 , tabel 10 , dan tabel 11 merupakan citra MRI dengan kondisi terdapat gangguan (lesi). Dari tabel 12 dapat dilihat bahwa program yang dirancang pada penelitian ini mampu bekerja pada citra dengan ekstensi yang berbeda.

a. Hasil kompresi

Berdasarkan hasil pada tabel 12 terlihat bahwa secara visual dari ketiga citra uji coba tersebut, hasil kompresinya masih terlihat jelas antara obyek citra dan latar belakang. Ketiga masih tersebut masih terlihat dengan jelas bahwa citra tersebut citra dengan gangguan (lesi). 
b. Rasio kompresi

Berdasarkan hasil pada tabel 12 terlihat bahwa citra dengan ekstensi “.jpg” memiliki rasio kompresi paling besar dibandingkan kedua citra uji coba lainnya yaitu 56,42\% . Sedangkan citra ekstensi “.bmp” memiliki rasio kompresi paling kecil yaitu 0,48\%. Artinya citra dengan ekstensi “.bmp” paling sedikit kehilangan informasi ketika dikompresi dibandingkan dengan citra ekstensi “.jpg” dan citra ekstensi “.png”.

c. Waktu kompresi

Berdasarkan hasil pada tabel 12 terlihat bahwa citra uji dengan ekstensi “.bmp” membutuhkan waktu yang lebih lama dibandingkan dengan citra dengan ekstensi “.png” dan “.jpg” yaitu sebesar 224,84 detik. Sedangkan waktu kompresi paling cepat adalah citra dengan ekstensi “.jpg” yaitu sebesar 222,64 detik.

d. MSE

Berdasarkan hasil pada tabel 12 terlihat bahwa nilai MSE paling kecil adalah citra dengan ekstensi “.bmp” yaitu sebesar 0,00106. Ini menunjukkan citra kompresi ekstensi “.bmp” lebih mirip dengan citra aslinya dibandingkan dengan citra ekstensi “.jpg” dan “.png”.

e. PSNR

Berdasarkan hasil pada tabel 12 terlihat bahwa citra dengan ekstensi “.bmp” memiliki nilai PSNR paling besar dibandingkan kedua citra uji coba lainnya yaitu sebesar 30,737. Sedangkan citra ekstensi “.png” sebesar 29,718 dan citra ekstensi “.jpg” sebesar 28,958. Ini menunjukkan kualitas kompresi citra ekstensi “.bmp” lebih bagus dibandingkan dengan citra ekstensi “.png” dan “.jpg”

\section{Penutup}

\subsection{Kesimpulan}

Berdasarkan hasil penelitian dan pembahasan maka dapat disimpulkan bahwa program yang dirancang untuk kompresi citra MRI menggunakan algoritma k-means dapat berjalan dengan baik dan sesuai dengan yang diharapkan.

Citra asli dan citra hasil kompresi secara visual tidak terlihat adanya perbedaan kualitas yang signifikan meskipun terjadi perubahan ukuran file. Hal ini disebabkan karena yang dikompresi adalah informasi yang dianggap kurang penting. Sehinggga mampu mengurangi penggunaan memori tanpa harus kehilangan kandungan informasi yang penting.

Algoritma $k$ means yang diusulkan pada penelitian ini dapat bekerja dengan baik pada citra ekstensi “.png”, “.jpg”, dan “.bmp”. Ini dapat dilihat dari nilai rasio kompresi, MSE, dan PSNR yang dihasilkan masing-masing ekstensi. Dari keseluruhan proses, nilai MSE yang paling tinggi dan PSNR yang paling rendah adalah citra dengan ekstensi “.jpg”. Sedangkan nilai MSE yang paling kecil dan PSNR yang paling besar adalah citra dengan ekstensi “.bmp”.

Berdasarkan hasil penelitian waktu yang dibutuhkan untuk proses kompresi yang paling singkat adalah citra dengan ekstensi “.jpg” baik pada citra MRI yang normal maupun citra MRI yang terdapat gangguan. Sedangkan waktu yang dibutuhkan proses kompresi yang paling lama adalah citra MRI dengan ekstensi “.bmp”.

\subsection{Saran}

Pada penelitian yang akan datang dapat digunakan teknik kompresi citra dengan menggunakan metode yang lainnya dan data citra MRI yang lain (selain citra MRI Otak) yang memungkinkan memiliki tingkat kompresi yang lebih tinggi dengan memperhatikan kualitas citra yang terkompresi akan menjadi lebih baik daripada penelitian sekarang.

\section{Daftar Pustaka}

Gonzalez, \& Woods. (2002). Digital Image Processing, 2nd Edition. Prentice Hall. 
http://sciencephoto.com/. (n.d.). Retrieved from http://sciencephoto.com/

Irwanto, Purwananto, Y., \& Soelaiman., R. (2012). Retrieved from http://digilib.its.ac.id/public/ITS-paper-25768-5106100137-Paper.pdf

Jani, S. (2012). An Efficient K-Means and C-Means Clustering Algorithm for Image. International Journal of Engineering Research \& Technology (IJERT), Vol. 1 Issue 5 ISSN: 2278-0181.

Masatu, D. A., Soesanti, I., \& Nugroho, H. A. (2014). Retrieved from http://ejpteti.jteti.ugm.ac.id/index.php/JPTETI/article/viewFile/4/2

Michaell. (n.d.). Chapter 4 Measures of distance between samples: Euclidean. Retrieved from http://www.econ.upf.edu/ michael/stanford/maeb4.pdf

Narwati. (n.d.). Pengelompokan Mahasiswa Menggunakan Algoritma K-Means. p. http://www.unisbank.ac.id/ojs/index.php/fti2/article/download/890/448.

Riantini, S. A. (2011). Retrieved from http://repodig.untan.ac.id/senayan/index.php?p=fstream-pdf\&fid=94\&bid=94

Rohman, M., \& Anisah, I. (2013). Retrieved from http://eprints.upnjatim.ac.id/4759/1/071078_Miftahur_Rohman_2_-_ITS.pdf

Sutoyo, T., Eddy, M., Vincent, S., Oky, D. N., \& Wijanarto. (2009). Teori Pengolahan Citra Digital. Yogyakarta: Andi.

Thyagarajan, K. S. (2011). Still Image And Video Compression With Matlab. A John Wiley \& Sons, Inc., Publication. 